Plant Syst. Evol. 244: 55-67 (2004)

DOI $10.1007 / \mathrm{s} 00606-003-0067-1$

Plant Systematics

and Evolution

Printed in Austria

\title{
Pollination by fungus gnats (Diptera: Mycetophilidae) and self-recognition sites in Tolmiea menziesii (Saxifragaceae)
}

\author{
P. Goldblatt ${ }^{1}$, P. Bernhardt ${ }^{2}$, P. Vogan $^{2}$, and J. C. Manning ${ }^{3}$ \\ ${ }^{1}$ B. A. Krukoff Curator of African Botany, Missouri Botanical Garden, St. Louis, Missouri, USA \\ ${ }^{2}$ Department of Biology, St. Louis University, St. Louis, Missouri, USA \\ ${ }^{3}$ National Botanical Institute, Claremont, South Africa
}

Received December 16, 2002; accepted August 8, 2003

Published online: February 3, 2004

(C) Springer-Verlag 2004

\begin{abstract}
Observations of insects visiting strongly protandrous flowers of Tolmiea menziesii (Saxifragaceae) show that Gnoriste megarrhina (Mycetophilidae), a large fungus gnat with a body ca. $7 \mathrm{~mm}$ long and a proboscis ca. $6.5 \mathrm{~mm}$ long, is the primary pollinator. Pollen is transferred to ventral portions of the gnat's thorax while it probes for an unusually dilute nectar $(8.3 \%$ to $12 \%$ sucrose equivalents) produced at the base of the floral tube. Grains are transferred to the two receptive stigmas on each pistil when it forages for nectar on a female phase flower. Pollen load analyses indicate that Tolmiea menziesii may be the only nectar source visited by the gnat while it is in bloom. While hoverflies (Syrphus spp.) and bumblebees (Bombus spp.) also visit T. menziesii flowers, they do not forage for nectar and usually behave as pollen robbers visiting only male phase flowers after earlier visits by G. megarrhina. When the modes of floral presentation of $T$. menziesii are compared to other species pollinated primarily by micro-dipterans, and mycetophilids in particular, there appears to be a floral convergence in some spring-flowering, perennial herbs of moist, evergreen woodlands and forests. Analyses of open (gnat-pollinated) vs. hand-pollinated pistils show that manual cross-pollinations are slightly more successful than open pollinations. Fluorescence microscopy confirms two sites of
\end{abstract}

self-recognition and rejection within the pistil: following controlled self-pollination experiments almost half of the pollen tubes produced either stop growing once they reach the top of the ovary and/or grow horizontally. The remaining tubes produced by self-pollination penetrate ovules but seed is never set. This double mode of self-recognition and rejection is similar to the one described for Heuchera micrantha var. diversifolia (Saxifragaceae) but may also confirm an earlier report of post-zygotic rejection made for Tolmiea.

Key words: Tolmiea, Saxifragaceae, pollination, nectar, protandry, pollen tube growth, Gnoriste, fungus gnats, Mycetophilidae.

Species of the family Saxifragaceae have served as model systems for floral biologists since the early 20th century. For example, they have been used repeatedly to determine the role(s) of dicliny, dichogamy and distyly as selfisolation mechanisms (Knuth 1908, Faegri and van der Pijl 1979, Ornduff 1975) while Primack (1985) used them as prime examples of the positive correlation between reductions in the number of organs per flower and an increasing floral life span. 
Interpretations of the pollination ecology of members of the Saxifragaceae have changed since the 19th century when naturalists listed all insect visitors found on their flowers as evidence of generalist pollination systems. Knuth (1908) reinterpreted some of this information to suggest that certain species were pollinated primarily by true flies (Diptera), while others depended on butterflies and moths (Lepidoptera). More recent evidence of specialized pollination systems in the family include Ornduff $(1971,1975)$, who noted that populations of Jepsonia heterandra were pollinated by a combination of small bees and hover flies, and Pellmyr et al. (1996) who showed that moths of the genus Greya are primary pollinators of Lithophragma parviflorum Nutt. ex Torr. \& A. Gray, Heuchera cylindrica Dougl. and Mitella stauropetala Piper. The role of Greya politella shifts between pollinator and seed parasite (Thompson and Cunningham 2002).

Pollen-pistil interactions within the family also suggest unusual variability. While heteromorphic and homomorphic species may be strongly self-incompatibile, the rejection of self-pollination is gametophytic, as it occurs after pollen tubes penetrate much of the length of the style (Rabe and Soltis 1999). More important, there may be more than one site of self-recognition and rejection. In Heuchera micrantha var. diversifolia more than $50 \%$ of the pollen tubes of self-pollinations stop in the style while the remainder stop in the ovary and/or ovule (Rabe and Soltis 1999).

Pollination and self-isolation mechanisms were studied by Weiblen and Brehm (1996) to determine why the sympatric and highly intercompatible species, Tellima grandiflora Pursh and Tolmiea menziesii (Pursh) Torr. \& A. Gray, rarely hybridized. They concluded that interspecific isolation was encouraged, in part, by divergent modes of floral presentation with Tellima grandiflora pollinated by beetles while Tolmiea is dependent on bumblebees, additional visits from hover flies (Syrphus sp.) and solitary bees (Halictus sp.). The authors also studied self-incompatibility in T. menziesii and concluded that there was a late rejection mechanism as pollen tubes based on selfpollination regularly penetrated ovules.

An interpretation of large bee and hover fly pollination in Tolmiea menziesii, a species that extends from coastal central California through western Oregon, Washington, and British Columbia to coastal southern Alaska (Hickman 1993), conflicts with its floral presentation. While large-bodied bees do pollinate small flowers, such minute blossoms are usually congested into a head or densely cymose inflorescence to provide united landing platforms (e.g. in Asteraceae), unlike the loose raceme of $T$. menziesii. Futhermore, this species fails to produce discernibly sweet floral odors and its flowers are dull colored and have filiform petals. Specifically, floral presentation in Tolmiea appears to converge with angiosperms associated with sapromyiophily (sensu Faegri and van der Pijl 1979; Vogel 1954, 1979), in which the primary pollen vectors are flies that lay their eggs in fungal fruiting bodies, or dung, or detritus, and/or animal corpses. The late-acting mode of self-incompatibility in $T$. menziesii may also be more complicated than the description provided by Weiblen and Brehm (1996). More than one site in the same pistil may recognize and reject pollen tubes produced by self-pollination (Rabe and Soltis 1999). An earlier but very limited study by Sears (1937) suggests that $T$. menziesii may reject young embryos produced by self-pollination.

For this reason, we have completed a twoyear field and laboratory study, reexamining the floral biology of Tolmiea menziesii. Our results test the hypotheses that this species is pollinated primarily by bumblebees and hoverflies and that the majority of ovules contain pollen tubes following self-pollination.

\section{Materials and methods}

Populations of Tolmiea menziesii (common names: youth-on-age, piggy-back plant) were observed at study sites in northwestern Oregon in two field seasons in 2001 and 2002 from early May to late 
June (Table 1). Plants were also examined in the field for attractants (floral odor, color signals) and rewards (nectar, pollen) as outlined elsewhere (Goldblatt et al. 1995, 1998a, 2000a, 2000b, 2003; Goldblatt and Manning 2000).

Insects observed visiting flowers and contacting either the anthers or stigmas were netted or captured by hand and killed in jars containing ethyl acetate fumes. Captured insects were examined for the presence of pollen first visually, and then pollen samples were removed from their bodies using a dissecting needle and mounted on slides in Calberla's fluid (Ogden et al. 1974). Pollen grains were identified and counted under the compound microscope after Goldblatt and Bernhardt (1990).

Nectar volume was measured from 10:00h to 12:00h using calibrated $2 \mu \mathrm{m}$ micropipettes measuring $55 \mathrm{~mm}$ in length. Micropipettes were used to carefully probe the base of the floral tube without damaging hypanthium tissue to avoid sample contamination. The percentage of sucrose equivalents in nectar taken from plants growing in the field was measured in the field using a Bellingham and Stanley hand-held refractometer $(0-50 \%)$.

We repeated the hand-pollination experiments of Weiblen and Brehm (1996) in the laboratory using cut stems due to persistent tourist traffic and trampling at our sites. These flowers, now excluded from contact with insects, were either left untouched as controls to determine whether mechanical self-pollination (autogamy) occurs, or pollen was applied by hand to exposed stigmas following expansion and separation of the two styles on each pistil. The two stigmas/flower received either pollen from a flower on the same inflorescence (selfpollination, geitonogamous cross) or pollen from a flower of a different plant, assumed to be a distinct genotype (cross-pollination, xenogamous cross). At the end of 24 hours after hand pollination whole flower were excised and fixed in 3:1 95\% ethanol/ glacial acetic acid. After one hour fixed flowers were transferred to $70 \%$ ethanol. To observe pollen tube penetration of female tissue, pistils were excised from floral receptacles and soaked in a $10 \% \mathrm{NaSO}_{3}$ solution for 24 hours at room temperature then taken through three baths of de-ionized water before squashing, staining and observation under epifluorescence following Goldblatt and Bernhardt (1990). Pollen tubes in styles were so closely constricted and pressed together that counts were not taken until the pollen tubes were observed to enter the much expanded ovary chambers (locules). To compare results of pollen tube penetration in open (insectpollinated controls) vs. bagged and hand-manipulated cross- and self-pollinations we ran an ANCOVA, testing the hypothesis that there is no difference between the number and length of pollen tubes in an ovary regardless of how the pistils were pollinated.

To compare and contrast rates of natural (open) pollinations, we collected nine flowers with separate, expanded styles, at random, from nine inflorescences of nine separate genets. These flowers were fixed and their pistil contents analyzed as above.

Plant vouchers are housed at the Missouri Botanical Garden herbarium (MO). Insects were identified by Scott Fitzgerald (Mycetophilidae), Oregon State University, Corvallis, Oregon; C. Thompson (Syrphidae) U.S.D.A. (Beltsville); R. Thorp (bumblebees), University of California, Davis. Vouchers are deposited respectively at these three institutions.

\section{Results}

Vegetative/reproductive morphology and nectar secretion. Tolmiea menziesii, the only species of the genus, occurs in damp shady situations, usually close to streams. Plants are perennial with a tuft of basal leaves and elongated, simple or branched flowering stems that bear terminal racemes of small, spirally arranged flowers. The dull purple, brownish or occasionally greenish perianth is held horizontally

Table 1. Study sites, all in the U.S.A., and voucher information. Herbarium vouchers are housed at the Missouri Botanical Garden, St. Louis

\begin{tabular}{ll}
\hline Location & Voucher data \\
\hline Eagle Creek, Hood River Co, OR & Goldblatt 11654 \\
Tryon Creek, Lake Oswego, Clackamas Co., OR & Goldblatt 11655 \\
MacLeay Park, Portland, Multnomah Co., OR & Goldblatt 11655A \\
\hline
\end{tabular}




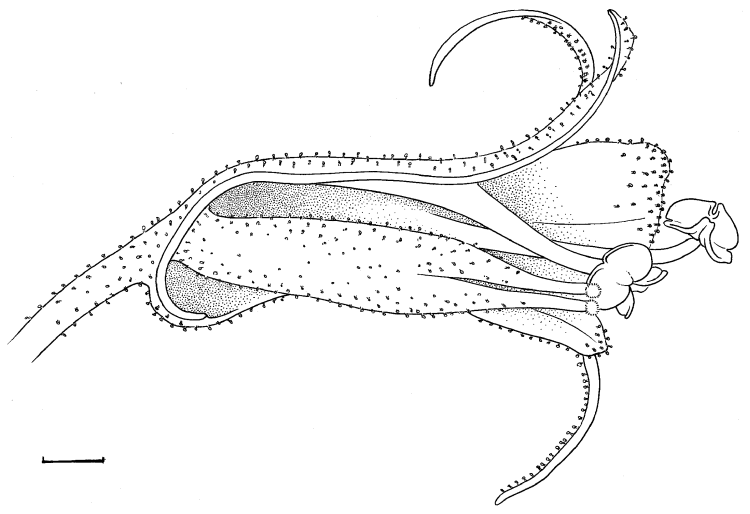

Fig. 1. Section of a flower of Tolmiea menziesii. Scale bar $=1 \mathrm{~mm}$. Drawn from preserved material and photographs by J. C. Manning

and is bilaterally symmetrical (Fig. 1). The flowers are evidently odorless to the human nose whether smelled as a freshly picked, bunched bouquet or confined to glass vials for 15-30 minutes to allow build up of odor. The calyx, corolla, and three stamens are united in a cylindrical floral (hypanthium) tube ca. $5 \mathrm{~mm}$ long. The tube is slit almost to the base abaxially where it forms a small pouch. The inner surfaces of the five pale greenish calyx lobes (sepals) have a radiating pattern of darker, purple-brown veins. The sepals are unequal, with the adaxial three larger and obtuse, while the abaxial two are shorter, acute and directed forward. The four corolla lobes (petals) alternate with the sepals but there is no petal between the abaxial pair of sepals (where the floral tube is slit).

Nectar droplets are visible by 09:00h as glistening spots on the proximal inner walls of the perianth tube around the base of the ovary. Nectar quantity per individual flower ranges from $>0.1$ to $0.2 \mu \mathrm{l}$ (Table 2) and mean nectar concentration ranges from 8.3 to $12.0 \%$ sucrose equivalents in two populations sampled on three separate days. Three stamens, opposite the upper (adaxial) sepals are unilateral, and arch downward to lie horizontally, oriented just above the abaxial pair of sepals. They extend for ca. $2 \mathrm{~mm}$ beyond the floral tube and spreading tepals and bear conspicuous, bright orange pollen (a few genotypes have dull yellow pollen). The bilocular, superior ovary is contained entirely within the corolla tube at anthesis. Bilobed above, the ovary consists of two carpels which taper distally into twin styles with terminal stigmas (Fig. 1).

The fruit is a two-chambered greenish, but ultimately light brown, thin-walled, translucent capsule that dehisces prior to the maturation of the seeds (green, unripe seeds are clearly visible through the open slit at the apex of each capsule). Mature black seeds spill though the open slits of the capsules as early as two weeks after fertilization. A mean of 90.4 seeds per capsule was counted $(n=7$ flowers from seven separate inflorescences); min$\max =42-155$ ).

Floral phenology and life-span. The flowering season of all populations of Tolmiea studied begins in early to mid May and lasts until about the end of June. Flowers are longlived, lasting six to eight days but are protandrous. That is, stamens are visible the day before anthers dehisce as soon as the calyx lobes separate. Once dehisced, bright orange pollen is clearly visible on the inner surfaces of the anthers. Flowers remain in this exclusively male phase for three to four days ( $n=5$ flowers

Table 2. Nectar properties in Tolmiea menziesii populations. Sample size indicates number of flowers (of different individuals) examined at study site or date

\begin{tabular}{llll}
\hline Study site & Sample size $(\mathrm{n})$ & \multicolumn{2}{l}{ Nectar } \\
\cline { 3 - 4 } & & volume $\mu \mathrm{l}(\mathrm{n})$ & $\%$ sugar $(+\mathrm{SD})$ \\
\hline Eagle Creek $5 / 20 / 02$ & 5 & $<0.1-1.84$ & $12.0(3.7)$ \\
Eagle Creek $5 / 31 / 02$ & 5 & $<0.1-0.21$ & $10.9(2.6)$ \\
Tryon Creek 5/24/02 & 5 & $<0.1-0.22$ & $8.3(2.0)$ \\
\hline
\end{tabular}


observed). At this time the two styles lie parallel and appressed to one another and are $2-3 \mathrm{~mm}$ long, as measured from the top of the ovary chamber to the stigma, which lies at the apex of the style.

On the fourth day of anthesis the styles diverge from one another in the vertical plane and elongate, reaching twice their original length, ca. $6 \mathrm{~mm}$ long. They emerge from the mouth of the perianth tube and come to lie in the same plane as the stamens with the stigmas extended almost to the level of the anthers. Stigma to stigma distance is ca. $3 \mathrm{~mm}$. By the time the styles and stigmas are visible outside the tube, all pollen is usually lost from the anthers in the wild as a result of insect activity and the flowers may remain in an exclusively female phase for another two or three days. In wild collected plants observations show that by the time the upper flowers of an inflorescence are open, the capsular fruits produced by the lower flowers contain ripe seeds that fall from the now suberect capsules if they are shaken or inverted.

Insect foraging. Observations at all study sites totaling over 35 hours yielded three groups of insects visiting flowers of Tolmiea menziesii (Table 3). From 9:00h until noon the dominant floral foragers were small light brown gnats, later identified as Gnoriste megarrhina (Mycetophilidae) (Fig. 2), and occasionally hoverflies, Syrphus spp. (Syrphidae). Individual gnats were observed to forage for nectar with their much elongated probosces, ca. $6.5 \mathrm{~mm}$ in length (Table 4). The foraging patterns of $G$. megarrhina included entering flowers, flying from one plant to another, and visiting other flowers of the same species. We limited our netting and capture to no more than 10 gnat individuals on any day but many more gnats were seen visiting flowers (Table 3) than were captured. A gnat typically crawled over the outside of a Tolmiea flower before moving to the mouth of the perianth. It then grasped the calyx or corolla lobes with its legs and inserted its proboscis into the gullet-like floral tube (Fig. 3). Once in this position, a gnat's head was hidden from view but individuals could be identified by their two wings which extended beyond the tepals. Individual visits lasted from 20 to 35 seconds (mean 25.13 SD 11.29, $\mathrm{n}=8$ ).

Individuals of G. megarrhina have a body ca. $7 \mathrm{~mm}$ long (measured from the base of the proboscis to the tip of the abdomen) and a slender proboscis ca. $6.5 \mathrm{~mm}$ in length (mean $6.55 \mathrm{~mm}$ SD $0.18 ; \mathrm{n}=10$ ), which individuals used to probe the floral tube (Table 4). Gnats showed no interest in pollen consumption. The close "fit" of a gnat's body to the dimensions of Tolmiea flowers was notable. When grasping the sepals and placing the head at the mouth of the tubular flower, the slender proboscis is almost exactly the combined length of the floral tube plus the calyx lobes, ca. $7 \mathrm{~mm}$ (Table 4). At this time the ventral surface of the gnat's thorax made contact with the dehisced anthers or the extended stigmas of a flower.

All captured gnats from our study sites carried visible loads of orange pollen on the ventral parts of their thoraxes and proximal parts of the legs. The pollen was deposited on their bodies passively as they pushed their bodies into flowers. Under compound microscopy, pollen of Tolmiea menziesii was removed from gnat thoraces and was identified easily by a suite of three characters. The grains are small and globose (when rehydrated), have three broad sulci, and a relatively smooth, thin exine. All 37 flies examined for pollen loads carried $<100$ grains each of the pollen of $T$. menziesii pollen (Table 3) exclusively.

In contrast, syrphid flies did not forage for nectar. They alighted on perianth segments and probed the anthers with their probosces for pollen. All syrphids were captured on male phase flowers and none was seen visiting flowers in female phase when pollen was no longer present in anthers. Pollen load analyses showed that five of the nine syrphid specimens carried Tolmiea pollen on their bodies (Table 3) but pollen washes indicated that these were trace amounts consisting of less than 10 grains for each fly. 
Table 3. Insect visitors to Tolmiea flowers. Asterisk $\left(^{*}\right)$ indicates more individuals seen but not captured

\begin{tabular}{|c|c|c|c|c|c|}
\hline Study site & Date and time & Insect taxa & $\begin{array}{l}\text { No. with host } \\
\text { pollen only }\end{array}$ & $\begin{array}{l}\text { No. with host } \\
\text { and other } \\
\text { pollen }\end{array}$ & $\begin{array}{l}\text { No. with other } \\
\text { species or } \\
\text { no pollen }\end{array}$ \\
\hline \multirow[t]{9}{*}{ Eagle Creek } & $\begin{array}{c}\text { May 23/01: } \\
\text { 11:30-13:30 }\end{array}$ & Gnoriste megarrhina & $10^{*}$ & 0 & 0 \\
\hline & May 28/01 & G. megarrhina & $10^{*}$ & 0 & 0 \\
\hline & & Parasyrphus macularis & 0 & 1 & 1 \\
\hline & $\begin{array}{l}\text { May } 20 / 02 \\
12: 00-15: 00\end{array}$ & Bombus sitkensis & 0 & 2 & 1 \\
\hline & & Parasyrphus macularis & 2 & 0 & 1 \\
\hline & & Melastoma mellinum & 1 & 1 & 1 \\
\hline & & G. megarrhina & 2 & 0 & 0 \\
\hline & May $31 / 02$ & Gnoriste megarrhina & $10^{*}$ & 0 & 0 \\
\hline & & Latychaeris obscurus & 0 & 1 & 0 \\
\hline \multirow[t]{9}{*}{ Tryon Creek } & $\begin{array}{l}\text { June 1/01: } \\
\text { 16:30-17:30 }\end{array}$ & Bombus flavifrons & 0 & 2 & 0 \\
\hline & & G. megarrhina & 2 & 0 & 0 \\
\hline & $\begin{array}{l}\text { June 21/01: } \\
\text { 12:00-14:00 }\end{array}$ & Bombus sitkensis & 0 & 2 & 0 \\
\hline & & G. megarrhina & 3 & 0 & 0 \\
\hline & & Parasyrphus macularis & 0 & 0 & 1 \\
\hline & $\begin{array}{r}\text { May 24/02: } \\
11: 00-1: 00\end{array}$ & Bombus flavifrons & 1 & 1 & 1 \\
\hline & & Bombus caligenosus & 1 & 0 & 0 \\
\hline & & Parasyrphus insolitus & 1 & 0 & 0 \\
\hline & & Melastoma mellinum & 0 & 0 & 0 \\
\hline \multirow[t]{4}{*}{ McLeay Park } & $\begin{array}{c}\text { June } 20 / 01: \\
2: 30-4: 30\end{array}$ & G. megarrhina & 2 & 0 & 0 \\
\hline & $\begin{array}{c}\text { June 21/01: } \\
\text { 10:00-11:30 }\end{array}$ & G. megarrhina & 2 & 0 & 0 \\
\hline & & Bombus sitkensis & 0 & 2 & 0 \\
\hline & $\begin{array}{c}\text { June 27/01: } \\
1: 30-3: 00\end{array}$ & Melastoma mellinum & 0 & 0 & 2 \\
\hline
\end{tabular}

Bumblebees were observed foraging on Tolmiea menziesii from 13:00 to 17:00h. However no bumblebee was ever seen visiting a female phase flower. Bumblebees removed pollen from male phase flowers foraging rapidly from one male phase flower to the next on the same inflorescence, scraping pollen from anthers before moving to another inflorescence. Captured bees carried mixed loads of pollen on their bodies including Hydrophyllum tenuipes A. Heller
(Hydrophyllaceae) and Rubus sp. noted flowering nearby.

Relatively small amounts ( $>100$ grains each) of Tolmiea pollen were identified on the ventral thorax and abdomen of some bees (Table 3). Far larger quantities of Tolmiea pollen were identified with both the naked eye (due to their deep orange color) and by microscopic analyses of the contents of the bee's corbiculae (pollen baskets) on the hind legs. These pollen baskets also contained 


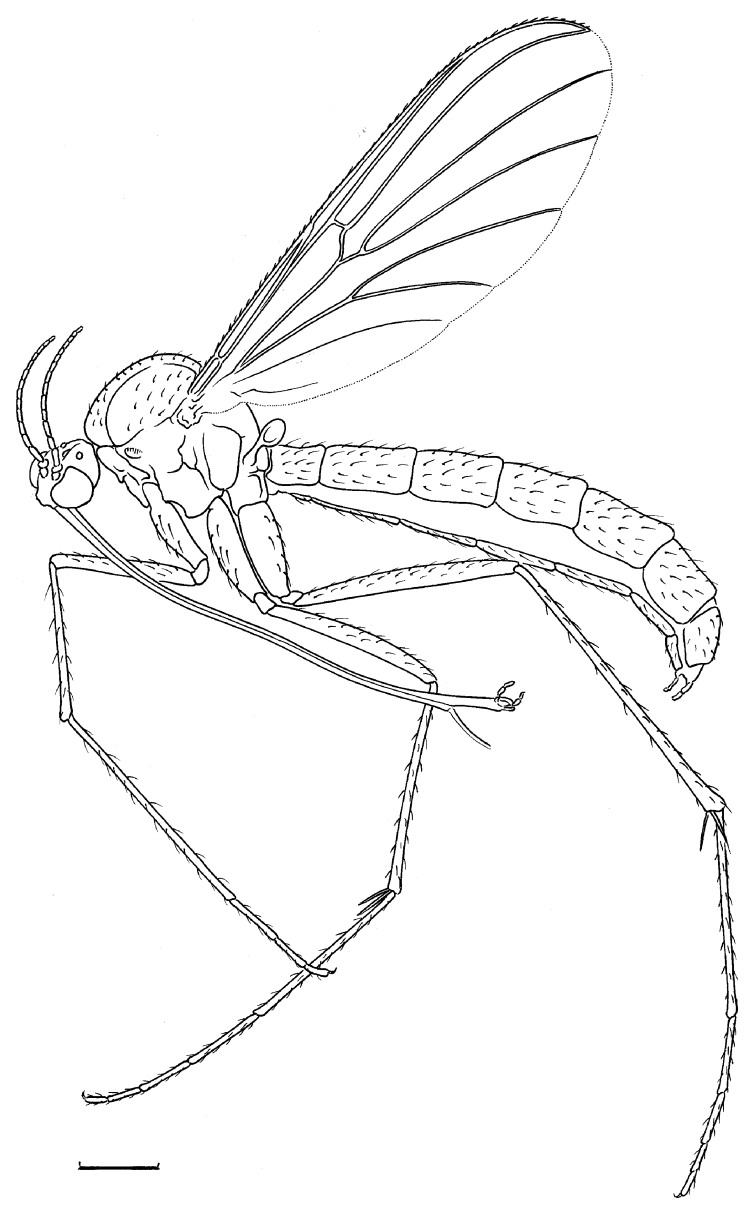

Fig. 2. The mycetophilid gnat, Gnoriste megarrhina. Scale bar $=1 \mathrm{~mm}$. Drawn from preserved material by J. C. Manning

pollen of co-blooming, Hydrophyllum and Rubus, often in discrete layers, the lower consisting of Hydrophyllum mixed with Rubus (both nectar-secreting flowers) while the outermost, bright orange-red layer consisted primarily of Tolmiea pollen. This suggested that Bombus species foraged on nectariferous
Hydrophyllum and Rubus earlier in the day, before visiting $T$. menziesii flowers and ignoring their sugar-poor nectar.

Flower to fruit conversion ratio. Fruit set in Tolmiea menziesii was often high. Open (gnat) pollinated inflorescences showed a conversion rate of $95 \%$ flowers carrying capsules $(n=10)$ at one study site. At a second site, perhaps due to weather or fewer available pollinators, showed $40-60 \%$ of flowers on an inflorescence forming mature capsules.

Fruit set. In the laboratory, all flowers left unpollinated fell from the flowering stalk by the eighth day of anthesis. All flowers selfpollinated by hand also fell from the stalk by the eighth day of anthesis $(n=20)$. All flowers cross- pollinated by hand were retained on the stalk, the ovary rapidly enlarged, and fruits developed to maturity $(n=10)$ but the resultant seeds were not examined for viability. We concur with Weiblen and Brehm (1996) that Tolmiea is self-incompatible, is incapable of mechanical autogamy and requires insect mediated cross-pollination before seed production may occur.

Comparative pollen tube penetration. We reject the null hypothesis that there is no difference in the number of pollen tubes penetrating styles and ovules based on whether pollenation was effected by gnats (open) or via manipulated cross- or self-pollinations $(\mathrm{F}(2,18)=9.01, \mathrm{P}<0.01)$. Hand-manipulated pollinations produce $>50 \%$ more pollen tubes in styles than gnat-mediated pollinations regardless of whether it is a cross- or selfpollination. However, the mean of pollen tubes penetrating ovules is $45 \%$ higher in cross- vs self-pollinations. In a self-pollination, 47 of the tubes grow no further than the top of the

Table 4. Significant floral and insect dimensions of Tolmiea menziesii and Gnoriste megarrhina

\begin{tabular}{|c|c|c|}
\hline Taxon & $\begin{array}{l}\text { Mean flower/insect } \\
\text { body length (SD) }\end{array}$ & $\begin{array}{l}\text { floral tube/proboscis } \\
\text { length } \mathrm{mm}\end{array}$ \\
\hline Tolmiea & ca. $8 \mathrm{~mm}$ & ca. 5 \\
\hline Gnoriste & $7.42 \mathrm{~mm}(\mathrm{SD} 0.53, \mathrm{n}=10)$ & mean $6.55(\mathrm{SD} 0.18, \mathrm{n}=10)$ \\
\hline Bombus sitkensis & $11.1 \mathrm{~mm}(\mathrm{SD} 01.34, \mathrm{n}=5)$ & mean $5.1(\mathrm{SD} 0.65, \mathrm{n}=5)$ \\
\hline
\end{tabular}




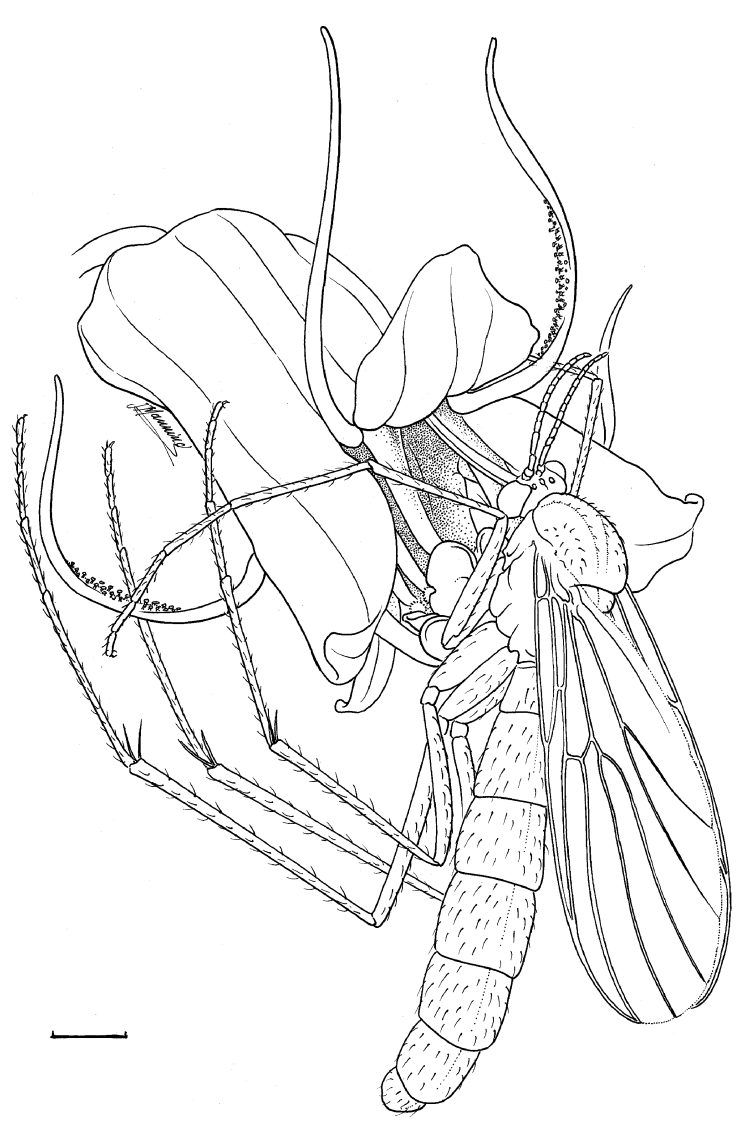

Fig. 3. Orientation of Gnoriste megarrhina on the flower of Tolmiea menziesii while foraging for nectar. Scale bar $=1 \mathrm{~mm}$. Drawn from preserved material and photographs by J. C. Manning

ovary (Table 5). Tubes that fail to grow further than the top of the ovary fail to show such typically aberrant signs of development as corkscrew or swollen or ruptured tips. Many tubes, however, appear to lose their "sense of direction" and grow horizontally within the ovary, often entering the base of the opposite style (Figs. 4 and 5).

\section{Discussion}

We agree with Weiblen and Brehm (1996) that different modes of floral presentation limit intergeneric hybridization between Tolmiea and Tellima grandiflora. However, bumblebees and syrphid flies were not primary pollinators of Tolmiea at our study sites. Successful pollination of $T$. menziesii appears to occur when there is passive contact (sensu Bernhardt 1996) between the pollen-bearing vector and receptive stigmas while the insect forages for nectar. Our field observations and pollen load analyses indicate that active pollen collection by syrphid flies is associated typically with unusually small quantities of pollen transported by these insects. Bumblebees, while massive collectors of pollen, avoided flowers in the female phase and we did not observe any individuals of either of these insect groups in contact with receptive stigmas of the host flowers.

Therefore, the primary pollinators of Tolmiea menziesii appear to be the fungus gnat, Gnoriste megarrhina, considering the "goodness of fit" between insect and flower. The gnat's proboscis is almost as long as its body and it carries significant loads of Tolmiea pollen after visiting several flowers for nectar. More important, gnats visit flowers in both male and female phase hours before the arrival of the first bumblebees. While a zygomorphic perianth is atypical for most flowers pollinated by Diptera, it is not uncommon (Vogel 1954, Proctor et al. 1996, Larson et al. 2001, Bernhardt and Goldblatt 2000, Goldblatt et al. 2003). We have already mentioned the presence of dull colors and filiform floral organs in sapromyiophilous flowers but the character of

Table 5. Comparative pollen tube penetrations in pistils of Tolmiea menziesii

\begin{tabular}{lllllll}
\hline Cross type & $\begin{array}{l}\text { Number of } \\
\text { pistils }\end{array}$ & $\begin{array}{l}\text { Ratio of styles } \\
\text { with tubes }\end{array}$ & \multicolumn{2}{l}{$\begin{array}{l}\text { Number of pollen tubes } \\
\text { in top of ovary }\end{array}$} & \multicolumn{2}{l}{$\begin{array}{l}\text { Number of pollen tubes } \\
\text { penetrating ovules }\end{array}$} \\
\cline { 4 - 7 } & & Mean & S.D. & Mean & S.D. \\
\hline Open & 6 & 0.66 & 29.83 & 30.35 & 27.83 & 28.66 \\
Cross & 9 & 0.83 & 62.56 & 41.02 & 58.22 & 43.24 \\
Self & 6 & 0.78 & 67.29 & 46.68 & 32.14 & 53.70 \\
\hline
\end{tabular}




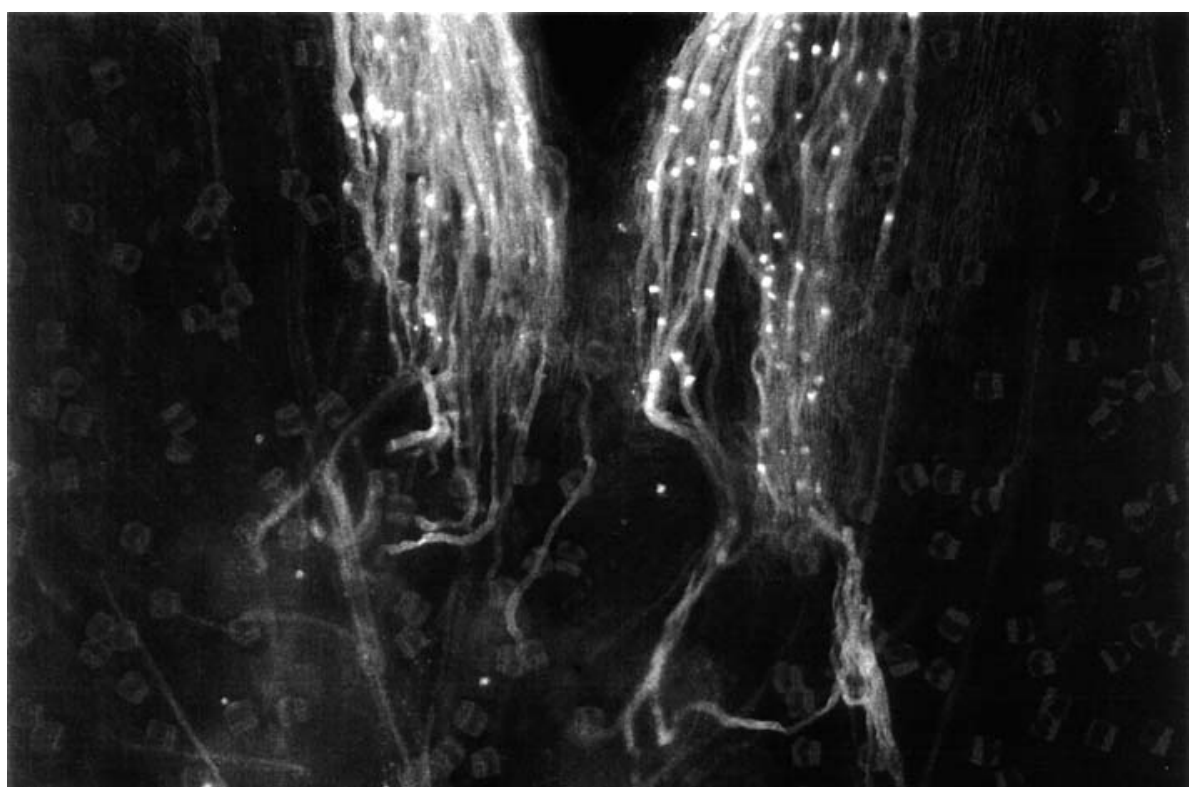

Fig. 4. Pistil self-pollinated by hand showing how the pollen tubes from each of the twin styles have stopped growing within the top half of the ovary. Note that approximately five tubes in the right hand bundle continue to grow downward. Brighly colored dots are the swollen heads of the transparent epidermal cells (cleared in $10 \%$ sodium sulphide solution). Scale x 75

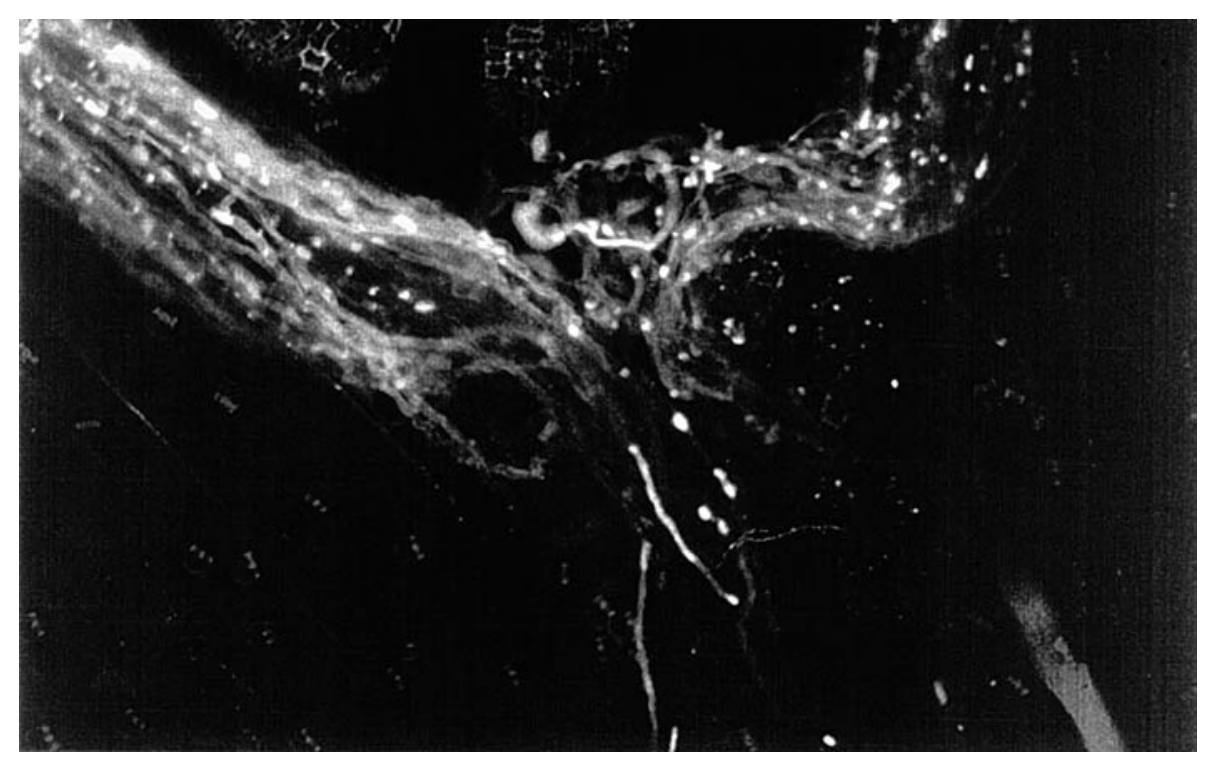

Fig. 5. Pistil self-pollinated by hand showing how the pollen tubes from each of the twin styles stop growing downward, change direction and grow toward each other. Note the approximately four tubes continuing to grow downward. Scale x 75

minute quantities of nectar with low levels of dissolved sugars could be added to this floral syndrome.
Tolmiea menziesii now joins the small but growing list of plants pollinated by fungus gnats in the Mycetophilidae and/or the related 
Sciaridae (Larson et al. 2001). Pollination by fungus gnats falls into two interrelated systems. Pollination by deceit is presumed in the genera Aristolochia (Aristolochiaceae, Stebbins 1971), Heterotropa (Asaraceae: Sugawara 1988), Corybas and Pterostylis (Orchidaceae: Dafni and Bernhardt 1990, Bernhardt 1995). In Heterotropa and Corybas pollination is believed to occur by brood site deception and only pregnant females are exploited. Pterostylis curta is interpreted as an example of sexual mimesis exploiting only male gnats. Tolmiea menziesii does not express either mode of pollination-by-deceit.

The second pollination system by fungus gnats offers an edible reward in the form of minute quantities of nectar. This has been recorded for Acianthus (Orchidaceae: Dafni and Bernhardt 1990), Scoliopus (Liliaceae s.l.: Mesler et al. 1980), and Listera cordata (L.) R. Br. (Orchidaceae: Ackerman and Mesler 1979). What is particularly significant about this reward system for gnats is that Listera cordata and Scoliopus also occur in the Pacific Northwest. Scoliopus, Listera cordata, and now Tolmiea are probably components of a syndrome more common in this region than anticipated. Pollination by fungus gnats may represent a significant reproductive trend within some floristic alliances within the Pacific Northwest. We suggest that fungus gnat pollination may be particularly advantageous to herbs confined to the forest floors and light gaps of mesic, cool, fungus-rich forests dominated by evergreen conifers. It is interesting to note that in Australia, Acianthus, Corybas and Pterostylis spp. are also associated with cool, wet, late winter-early spring flowering periods within shaded-to partially shaded woodlands and heathlands (Bishop 1996).

Most flies of the families of suborder Nematocera of the Diptera, to which the Mycetophilidae belong, are characterised by primitive suctorial mouth-parts mounted on a very short proboscis. Larson et al. (2001) observed that they are generally restricted to open flowers with exposed nectar or to flowers with short tubular perianths. Flowers visited by nematocerans include, in particular, some members of the Apiaceae, Brassicaceae, Euphorbiaceae, Rosaceae, Saxifragaceae, and some Asteraceae distributed through Greenland, North America and New Zealand (Cruden 1972, Primack 1983, Shaw and Taylor 1986, Proctor et al. 1996). Nematocerans are considered less important as dependable pollen vectors than their frequency of visitation might suggest. However this suborder contains many nocturnal species and observations of flowers at night are needed because these may greatly increase our recognition of their prevalence as potential pollinators. The ancient origin of Nematocera and their consumption of nectar as a carbohydrate fuel for flight places them as contenders for early pollinators of the first angiosperms (Willemstein 1987). Obviously, Gnoriste megarrhina is a most important exception to this rule when one considers the sheer length of its proboscis, particularly in relation to its body. Indeed, this insect's body is also twice the length of the diminutive Mycomya species identified as pollinators of Pterostylis and Corybas R. Br. (Bernhardt 1995, and see review in Dafni and Bernhardt 1990).

In turn, the dull-colored, zygomorphic and tubular flowers of Tolmiea menziesii are distinctive within the Saxifragaceae although vegetative growth in this species strongly resembles such genera as Heuchera, Mitella, and Tellima, to which it is so closely related (Soltis and Kuzoff 1995). Molecular analysis shows Tolmiea to belong to the Heucherina clade of the family (Soltis et al. 2001). Within that clade Tolmiea is distinguished from related genera by its floral zygomorphy, three stamens per flower, five unequal calyx lobes, and four filiform petals. In contrast, its closest relatives have radially symmetrical, pentamerous flowers with laminate petals. It is apparent that taxonomists have placed Tolmiea in a separate genus because its flower structure appears so divergent from related Saxifragaceae despite its inter-compatibility with Tellima.

While Tolmiea menziesii is an obligate outcrossing species, observations of fruit set and 
analyses of open (gnat) pollinated pistils show high rates of cross-pollination in situ. In contrast hand-pollination experiments indicate that self-isolation mechanisms between pollen and pistils require clarification and comparison with earlier studies on this species and other members of the same family. While there is no significance between the sheer numbers of pollen tubes penetrating style tissue following a self-pollination vs. a cross-pollination, the actual number of tubes that enter ovules following cross-pollination is dramatically higher. This is similar to hand-pollination experiments on the allied Heuchera micrantha var. diversifolia in which most pollen tubes produced by self-pollination stop growing once they reach the base of the style. The few remaining tubes enter the ovules but, as in T. menziesii, no fruits develop. Rabe and Soltis (1999) concluded that self-incompatibility in $H$. micrantha lay between gametophytic and late-acting incompatibility.

Are we actually looking at two, overlapping, self-incompatibility sites in the pistil of Tolmiea menziesii? A second interpretation is possible following review of a much earlier experiment by Sears (1937) who self-pollinated a single plant of $T$. menziesii. The author also noted that, while the majority of ovules in a self-pollinated pistil were not fertilized, the few that were developed a limited number of embryo cells (four-nine) and 20-60 endosperm nuclei (see Sears 1937; Plate I, Fig. 7). If Sears was correct then self-isolation in $T$. menziesii may not be based on two, "overlapping" selfincompatibility sites. It would be based on one, partial gameophytic mechanism in the ovary followed by a post-zygotic (embryonic lethal?) rejection during early phases of seed development. Controlled, hand-manipulated pollinations obviously produce more tubes in styles and more tubes penetrating ovules than open pollinations effected by gnats (Table 5).

We thank Scott Fitzgerald at Oregon State University, Corvallis, C. Thompson at USDA
Beltsville, and R. Thorp at the University of California, Davis, for help with identification of insects and helpful comments on insect biology.

\section{References}

Ackerman J. D., Mesler M. R. (1979) Pollination of Listera cordata (Orchidaceae). Amer. J. Bot. 66: 820-824.

Bernhardt P. (1995) Notes on the anthecology of Pterostylis curta (Orchidaceae). Cunninghamia 4: 1-8.

Bernhardt P. (1996) Anther adaptations in animal pollination. In: D'Arcy W.G., Keating R. C. (eds.) The anther; form, function and phylogeny. Cambridge University Press, Cambridge, U.K., pp. 192-220.

Bernhardt P., Goldblatt P. (2000) The diversity of pollination mechanisms in the Iridaceae of southern Africa. In: Wilson K., Weston P. (eds.) Monocots: systematics and evolution. CSIRO, Melbourne, pp. 301-308.

Bishop T. (1996) Field guide to the orchids of New South Wales and Victoria. University of New South Wales Press, Sydney, Australia.

Cruden R. W. (1972) Pollination biology of Nemophila menziesii (Hydrophyllaceae) with comments on the evolution of oligolectic bees. Evolution 26: 373-389.

Dafni A., Bernhardt P. (1990) Pollination of terrestrial orchids of southern Australia and the Mediterranean region: systematic, ecological and evolutionary implications. In: Hecht M. K., Wallace B., Macintyre R. J. (eds.) Evolutionary biology. Plenum, New York, pp. 193-252.

Faegri K., van der Pijl L. (1979) The principles of pollination ecology, 3rd edn. Pergamon Press, New York, New York, USA.

Goldblatt P., Bernhardt P. (1990) Pollination biology of Nivenia (Iridaceae) and the presence of heterostylous self-compatibility. Israel J. Bot. 39: 93-111.

Goldblatt P., Manning J. C. (2000) The longproboscid fly pollination system in southern Africa. Ann. Missouri Bot. Gard. 87: 146-170.

Goldblatt P., Manning J. C., Bernhardt P. (1995) Pollination biology of Lapeirousia subgenus Lapeirousia (Iridaceae) in southern Africa: floral divergence and adaptation for long-tongued flypollination. Ann. Missouri Bot. Gard. 82: 517-534. 
Goldblatt P., Manning J. C., Bernhardt P. (1998a) Floral biology of bee-pollinated Gladiolus species in southern Africa. Ann. Missouri Bot. Gard. 85: $492-517$.

Goldblatt P., Manning J. C., Bernhardt P. (2000a) Adaptive radiation of pollination systems in Sparaxis Ker Gawler (Iridaceae: Ixioideae). Adansonia sér. 3, 22: 57-70.

Goldblatt P., Manning J. C., Bernhardt P. (2000b) Adaptive radiation of pollination mechanisms in the African genus Ixia (Iridaceae: Crocoideae). Ann. Missouri Bot. Gard. 89: 564-577.

Goldblatt P., Manning J. C., Bernhardt P. (2003) Observations on the floral biology of Melasphaerula (Iridaceae: Crocoideae); is this monotypic genus pollinated by march flies (Diptera: Bibionidae)? Ann. Missouri Bot. Gard. 92(in press).

Hickman J. C. (ed.) (1993) The Jepson manual: higher plants of California. Univ. California Press, Berkeley, CA.

Johnson S. D., Steiner K. E. (1994) Efficient pollination of the mass-flowering Cape orchid Disa obtusa Lindl. (Orchidaceae) by Bibio turneri Edwards (Diptera: Bibionidae). African Entom. 2: 64-66.

Knuth P. (1908) Handbook of flower pollination based upon Hermann Muller's work "The fertilisation of flowers by insects". Transl. J. R. Ainsworth Davis. Clarendon Press, Oxford, United Kingdom.

Larson B. M. H., Kevan P., Inouye D. W. (2001) Flies and flowers: taxonomic diversity of anthophiles and pollinators. Canad. Entom. 133: 439-465.

Mesler M. R., Ackerman J. D., Lu K. L. (1980) The effectivness of fungus gnats as pollinators. Amer. J. Bot. 67: 564-567.

Ogden E. C., Raynor G. S., Hayers J. V., Lewis D. M. (1974) Manual of sampling airborne pollen. Hafner Press, London, United Kingdom.

Ornduff R. (1971) The reproductive system of Jepsonia heterandra. Evolution 25: 300-311.

Ornduff R. (1975) Complimentary roles of halictids and syrphids in the pollination of Jepsonia heterandra (Saxifragaceae). Evolution 29(2): 371-373.

Pellmyr O., Thompson J. N., Brown J. M., Harrison R. G. (1996). Sources of variation in pollinator contribution within a guild: the effects of plants and pollinator factors. Oecologia 107: 595-604.
Primack R. B. (1983) Insect pollination in the New Zealand mountain flora. New Zealand J. Bot. 21: 317-333.

Primack R. B. (1985) Longevity of individual flowers. Ann. Rev. Ecol. Syst. 16: 15-37.

Proctor M., Yeo P., Lack A. (1996) The natural history of pollination. Timber Press, Portland, OR.

Rabe A. J., Soltis D. E. (1999) Pollen tube growth and self-incompatibility in Heuchera micrantha var. diversifolia (Saxifragaceae). Int. J. Plant Sci. 160: $1157-1162$.

Sears E. R. (1937) Cytological phenomena connected with self-sterility in the flowering plants. Genetics 22: 1662-1682.

Shaw D. C., Taylor R. J. (1986) Pollination ecology of an alpine fell-field community in the North Cascades. Northwest Sci. 60: 21-31.

Soltis D. E., Kuzoff R. K. (1995) Discordance between nuclear and chloroplast phylogenies in the Heuchera group (Saxifragaceae). Evolution 49: 727-742.

Soltis D. E., Kuzoff R. K., Mort M. E., Zanis M., Fishbein M., Hufford L., Koontz J., Arroyo M. K. (2001) Elucidating deep-level phylogenetic relationships in Saxifragaceae using sequences for six chloroplastic and nuclear DNA regions. Ann. Missouri Bot. Gard. 88: 669-693.

Stebbins G. L. (1971) California pipevine: a light trap for unwary flies. California Native Pl. Soc. Newslett. 7: 4-5.

Sugawara T. (1988) Floral biology of Heterotropa tamaensis (Aristolochiaceae) in Japan. Plant Species Biol. 3: 77-12.

Thompson J. N., Cunningham B. M. (2002) Geographic structure and dynamics of coevolutionary selection. Nature 417: 735-738.

Vogel S. (1954) Blütenbiologische Typen als Elemente der Sippengliederung. Bot. Studien 1: $1-338$.

Vogel S. (1979) Pilzmuckenblumen als Pilzmimeten. [Fungus-gnat flowers mimicking fungi]. Flora 167: 329-398.

Weiblen G. D., Brehm B. G. (1996) Reproductive strategies and barriers to hybridization between Tellima grandiflora and Tolmiea menziesii (Saxifragaceae). Amer. J. Bot. 83(7): 910-918.

Willemstein S. C. (1987) An evolutionary basis for pollination ecology. E. J. Brill/Leiden University Press, Leiden. 
P. Goldblatt et al.: Pollination by fungus gnats (Diptera: Mycetophilidae)

Addresses of the authors: Peter Goldblatt (e-mail: peter.goldblatt@mobot.org), B. A. Krukoff Curator of African Botany, Missouri Botanical Garden, P. O. Box 299, St. Louis, Missouri 631660299, USA. Peter Bernhardt (e-mail: bernhap2@, slu.edu), Patrick Vogan, Department of Biology, St. Louis University, St. Louis, Missouri 63103, USA. John C. Manning (e-mail: manning@, nbict.nbi.ac.za), National Botanical Institute, P. Bag X7, Claremont 7735, South Africa 